\title{
The first African record of Artolenzites acuta comb. nov. (Basidiomycota, Polyporaceae)
}

\author{
Ambit RT ${ }^{1}$ and Mossebo DC ${ }^{*}$ \\ ${ }^{1}$ University of Yaoundé 1, Mycological Laboratory, B.P. 1456 Yaoundé, Cameroon
}

Ambit RT, Mossebo DC 2015 - The first African record of Artolenzites acuta comb. nov. (Basidiomycota, Polyporaceae). Mycosphere 6(3), 280-289, Doi 10.5943/mycosphere/6/3/6

\begin{abstract}
Lenzites acuta is recorded for the first time in Africa. Based on morphological and macrochemical features, the species is combined to the recently resurrected genus Artolenzites, and the new combination Artolenzites acuta is proposed here. Considering Artolenzites elegans, A. acuta constitutes the second known species in the genus Artolenzites.
\end{abstract}

Key words - Artolenzites - taxonomy - new combination - species - wood rotting fungi - Africa

\section{Introduction}

The genus Lenzites Fr. was first described by Fries in 1835 with Lenzites betulina (Fr.) Fr. as type species. This generic name which existed until very recently before the study by Welti et al. (2012) counted several species including Lenzites acuta Berk, L. elegans (Spreng.) Pat., L. stereoides (Fr.) Ryv. and L. vespacea (Pers.) Ryv. According to Ryvarden \& Johansen (1980) and Nŭnez \& Ryvarden (2001) the genus Lenzites is characterized by a smooth to slightly hirsute pileus; lamellate, daedaleoid and poroid hymenophore sometimes in the same fruitbody; trimitic hyphal system with thin-walled and clamped generative hyphae, hyaline and thick-walled skeletal hyphae, hyaline and strongly branched binding hyphae; cylindrical spores which are smooth, thinwalled, hyaline and non-amyloid. The genus Artolenzites was erected by Falc in 1909 (Kirk et al. 2008) with Daedalea repanda Pers. as the type and single species which is today known as a synonym of Artolenzites elegans (Spreng.: Fr.) Teixeira described by Teixera (1986). Following recent morphological and molecular phylogeny studies of Trametes and related genera carried out by Welti et al. (2012) on more than 30 species of the group, these authors came out with four distinct genera on a phylogenetic tree including: 1) Trametes with among others species Trametes betulina (former Lenzites betulina) and Trametes polyzona (former Coriolopsis polyzona), 2) Artolenzites including only the tropical Lenzites elegans, 3) Pycnoporus including Pycnoporus sanguineus and 4) Leiotrametes including L. lactinae and L. menziesii.

Also, based on the following striking points emphasized in their study and referring to the relationship between the type of hymenial surface and positioning of species on the phylogenetic trees generated, Welti et al. (2012) affirmed that: a) "There is no correlation at all between type of hymenial surface and phylogenetic position of a species within the Trametes-group", and b) "The lamellate Lenzites warnieri, Artolenzites elegans and Trametes betulina are not monophyletic and show no close relationship". Based on these remarks, the authors concluded: "Lenzites is therefore 
discarded", thereby declaring the cancellation of the genus Lenzites later on approved by Ryvarden \& Melo (2014).

Four samples of Polyporaceae were collected by the authors between 2006 and 2012 and initially identified as belonging to the genus Lenzites. Three of the four collections were at two occasions in 2006 and 2010 sent to Ryvarden (pers. comm.) who identified them as the first African record of Lenzites acuta Berk. The macro- and micromorphological characters of these collections conspicuously match the features of Lenzites acuta as described by various authors including Ryvarden \& Johansen (1980) and Nŭnez \& Ryvarden (2001).

Also it is worth underscoring the following key taxonomic data:

1) The genus Lenzites was recently cancelled as earlier mentioned according to phylogenetic studies carried out by Welti et al. (2012) and the genus Artolenzites confirmed by the authors as its substitute to include also the tropical Lenzites elegans, therefore renamed as Artolenzites elegans by Teixeira (1986)

2) The macro- and micromorphological features of our samples conspicuously match those of Artolenzites. In fact, when cross-checking these samples with the morphologic and macrochemical characters (Ref. Appendix Table 3) of genera in the Trametes-group as set up by Welti et al. (2012) and including Trametes, Pycnoporus, Leiotrametes, Artolenzites, T. ljubarskyi-T. cingulata \& L. warnieri, these specimens conspicuously match only the features of Artolenzites

3) One of the key micromorphological features of our samples is the absence of a resinous accumulation in the upper surface of skeletal hyphae and the absence of parietal crystals on hyphae from the pileipellis

4) Also, the differential $\mathrm{KOH}$ test set up by Welti et al. (2012) in the Trametes-group to which belongs the genus Artolenzites was for the first time successfully carried out on our samples

5) Our specimens originally identified by Ryvarden (pers. comm.) as the first record of Lenzites acuta from Africa also show other striking macro- and micromorphological features not yet described or illustrated in the existing literature

6) All descriptions done so far on Lenzites acuta were mostly literary with very little emphasis on accurate drawings and colour images of the above mentioned noteworthy features.

On the basis of all above mentioned data and other taxonomic parameters, we hereby describe the first African collection of Artolenzites acuta comb. nov. resulting from the combination of the genus Artolenzites and the former species Lenzites acuta. This new combination henceforth constitutes with Artolenzites elegans the second known species in this genus.

\section{Materials \& Methods}

\section{Collection and preservation of specimens}

The specimens examined were collected between 2006 and 2012 in Cameroon in the outskirts of Yaoundé $\left(03^{\circ} 52^{\prime} 21^{\prime \prime} \mathrm{N}, 11^{\circ} 31^{\prime} 03^{\prime \prime} \mathrm{E}\right.$ to $\left.03^{\circ} 51^{\prime} 38^{\prime \prime} \mathrm{N}, 11^{\circ} 30^{\prime} 07^{\prime} \mathrm{E}\right)$ in forestry areas at altitudes varying from 650 to $1250 \mathrm{~m}$. The specimens collected were photographed when possible just after collection and later on dried on a Dörrex electric dryer. Each specimen was thereafter attributed a HUY1-DMx herbarium number $(\mathrm{x})$ before preservation in the mycological herbarium of the University of Yaoundé 1 (HUY1) and duplicates were deposited at the Botany Division, Biological Institute of the University of Oslo in Norway.

\section{Macro- and micromorphological identification}

Methods used for the description and preliminary identification of specimens collected are general methods described by various authors (Ambit 2011, Charbonnel 1995, Erb \& Matheis 1983, Kengni Ayissi et al. 2014, Mossebo 2005, Mossebo et al. 2007, Mossebo \& Ryvarden 1997, 2003, Nŭnez \& Ryvarden 2001, Ryvarden \& Johansen 1980, Ryvarden 1992) and used for Polyporales description and identification. More specific methods for species belonging to the Trametes-group (Welti et al. 2012) and other daedaloid and hexagonoid polypores (González-Ball 
et al. 2004, Rathod 2011) were also used. Colours were characterized for the first time in this genus using the colour chart of Kornerup \& Wansher (1978). For micromorphology, free-hand thin sections were performed with razor blades on detached lamellae and tiny pieces of cuticle cut out from the basidiocarp in order to characterize the pileus structure according to the description of Welti et al. (2012). The sections realized were mounted in 5\% $\mathrm{KOH}$ and stained with the Melzer's reagent (Iodine $0.5 \mathrm{~g}$, Potassium iodine $1.5 \mathrm{~g}$, Hydrated chloral $20 \mathrm{~g}$ in $22 \mathrm{~cm}^{3}$ water) before observation with a compound microscope equipped with an eyepiece micrometer for measurements.

To examine the assignment of our specimens to the genera Trametes, Pycnoporus, Leiotrametes, Artolenzites, T. ljubarskyi-T. cingulata or L. warnieri, macro- and micromorphological criteria and a macrochemical test set up by Welti et al. (2012) were carried out on sporocarps. Features such as the upper surface of the pileus, type of attachment to the substrate, structure (poroid, lamellate, dentate, daedoloid, lenzitoid) of the hymenophore were particularly scrutinized. For micromorphology, the presence or absence of parietal crystals on hyphae from the pileus as well as the presence or absence of a black line below the tomentum were investigated under the microscope. The macrochemical test set up by Welti et al. (2012) consisted of testing the reaction of the pileus, context and hymenophore to $5 \% \mathrm{KOH}$.

\section{Specimens examined}

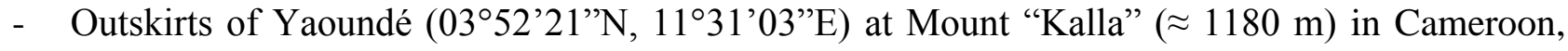
on a dead trunk of an unidentified angiosperm, 11-05-2006, D.C. Mossebo, HUY1-DM 456

- Nkomo $(\approx 770 \mathrm{~m})$ neighborhood in the outskirts of Yaoundé $\left(03^{\circ} 51^{\prime} 38^{\prime \prime} \mathrm{N}, 1^{\circ} 30^{\prime} 07^{\prime \prime} \mathrm{E}\right)$ in Cameroon, on a dead branch of an unidentified angiosperm, 14-11-2006, D.C. Mossebo, HUY1-DM 482

- Outskirts of Yaoundé $\left(03^{\circ} 52^{\prime} 21^{\prime}\right.$ N, $\left.11^{\circ} 31^{\prime} 03^{\prime} \mathrm{E}\right)$ at Mount "Kalla" ( $\left.\approx 1180 \mathrm{~m}\right)$ in Cameroon, on a dead stump of an unidentified angiosperm, 14-05-2010, D.C. Mossebo, HUY1-DM 575

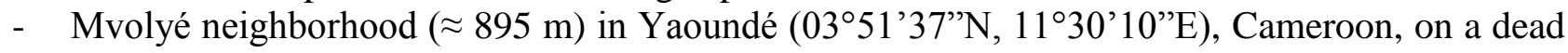
trunk of an unidentified angiosperm, 28-10-2012, D.C. Mossebo, HUY1-DM 865.

\section{Results}

Artolenzites acuta comb. nov. is described for the first time with colour images and accurate drawings of key macro- and microscopical features. Results of the new test to $5 \% \mathrm{KOH}$ are also presented and illustrated in colour images.

Artolenzites acuta (Berk) Mossebo \& Ambit comb. nov.

Figs. 1, 2, $3 \& 4$ MycoBank: MB 812287

Synonyms

Lenzites acuta Berk (1842)

Dadalea inaequabilis Berk (1843)

Daedalea flavida Lev. L.C. (1844)

Trametes lobata Berk (1851)

Lenzites becklerii Berk (1872)

Daedalea isabellina Murr. (1908)

Lenzites adusta Mass (1910)

Hexagonia flavofusca Lloyd (1922)

Fruitbody - annual to biannual, dimidiate or broadly attached to the substrate, in some cases substipitate, solitary or with few imbricate outgrowths (Fig. 1A2) of smaller basidiocarps over the pileus; measuring in average $24.8 \mathrm{~cm}$ long, $14.7 \mathrm{~cm}$ wide and $3.5 \mathrm{~cm}$ thick at the base towards the attachment point to the substrate; \pm flexible even for exsiccata; pileus most often multicoloured in the tropics according to the fresh or dry state of basidiocarps upon collection. 

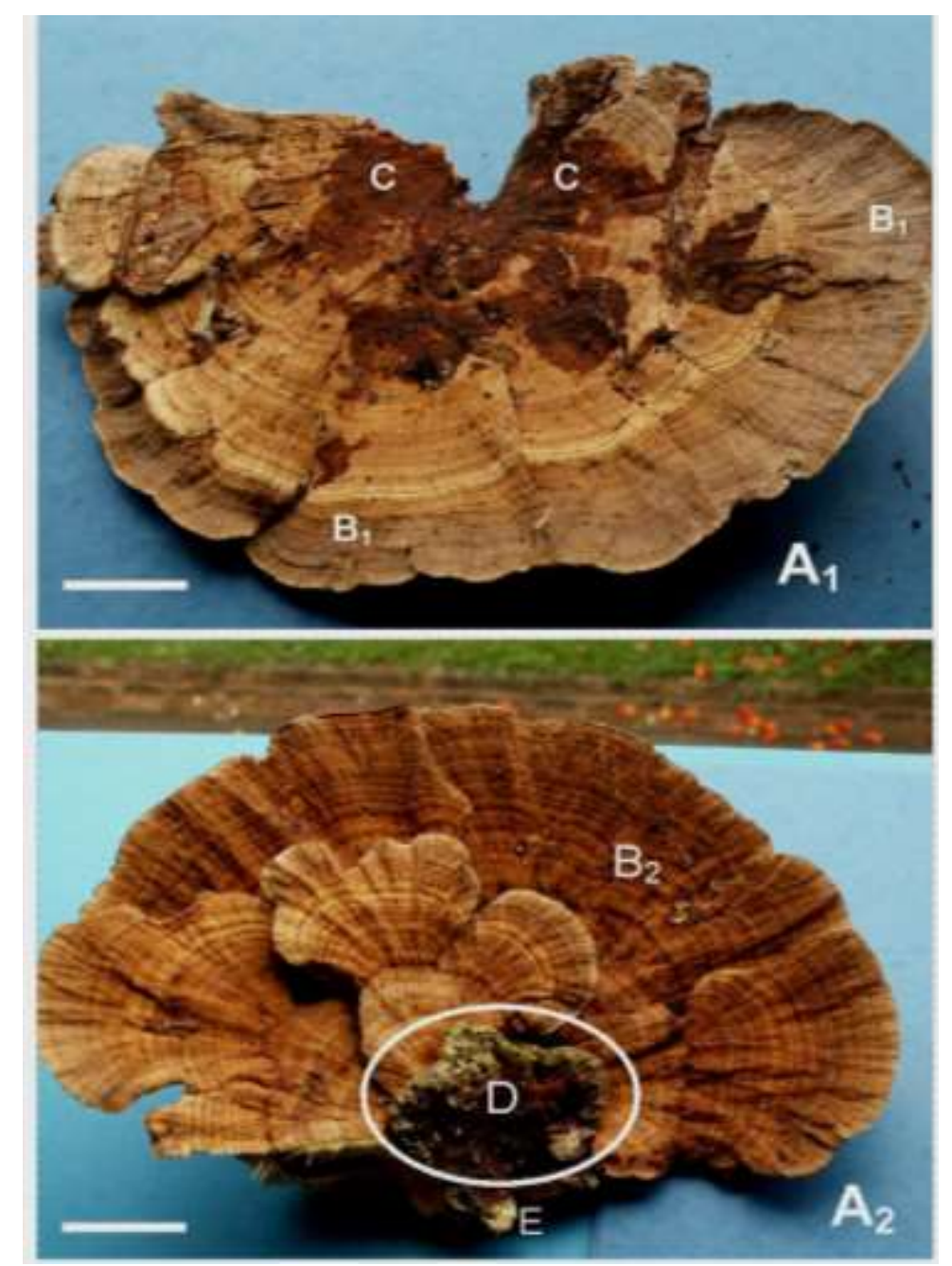

Fig. $1-A_{1} / A_{2}$ Artolenzites acuta comb. nov. $B_{1} / B_{2}$ Upper part of the pileus showing concentric zones. C Basal part of the pileus generally contrasting in colour with the upper part. D Disk at the base of the pileus towards the attachment point to the substrate. E Piece of the attachment to the substrate contracted into a stem-like base. Scale bar A1/A2 $=3 \mathrm{~cm}$.

Fresh basidiocarps either \pm uniformly light brown to brown (6D5-6D6) or golden brown (5D7$5 \mathrm{D} 8), \pm$ concentrically zonate (Figs. 1A1/1A2/4B) and showing from the borders towards the base a succession of greyish brown (7C2-7C3) to dark grayish brown (7D4-7E4) colours and thereafter a brownish to pale orange (5A3, 5B3-6D4) with clay coloured to dirty brown (7D7-7D8) spots originating from the base (Fig. 1C) of the pileus. These clay colour spots sometimes extend over the lower half of the pileus or are rather restricted to the disc on basidiocarps showing a disc (Fig. 1D/4D) at the attachment point to the substrate, disc sometimes contracted into a stem-like (Fig. $1 \mathrm{E} / 4 \mathrm{E})$ base.

Dry basidiocarps most often either uniformly beige to pale ochraceous (4A2-4A3), colour sometimes restricted to the borders of the pileus or rather showing a succession of : beige to dirty brown (6D3) or dirty grayish (6D2) in the upper part of the pileus / clay colour (7D7-7D8, 7E6$7 \mathrm{E} 7)$ in the central part / and dark reddish brown to violet brown $(10 \mathrm{~F} 3-10 \mathrm{~F} 4,11 \mathrm{~F} 3-11 \mathrm{~F} 4)$ at the base of old specimens. Pileus surface most often glabrous, slightly sulcate or \pm concentrically zonate with inconspicuous radial ridges on some specimens; margin sharp, entire or slightly lobed.

Hymenophore - extremely variable, sometimes combining lamellate (Fig. 2A/ $/ 1_{1}-1_{2}$ ), daedeloid (Fig. 2A-da, Fig. 2C-da) and poroid (Fig. 2A/p p $_{1}$ - p $_{2}$ structures on the same hymenophore, or just lamellate in some specimens with lamellae showing most often and particularly on young 


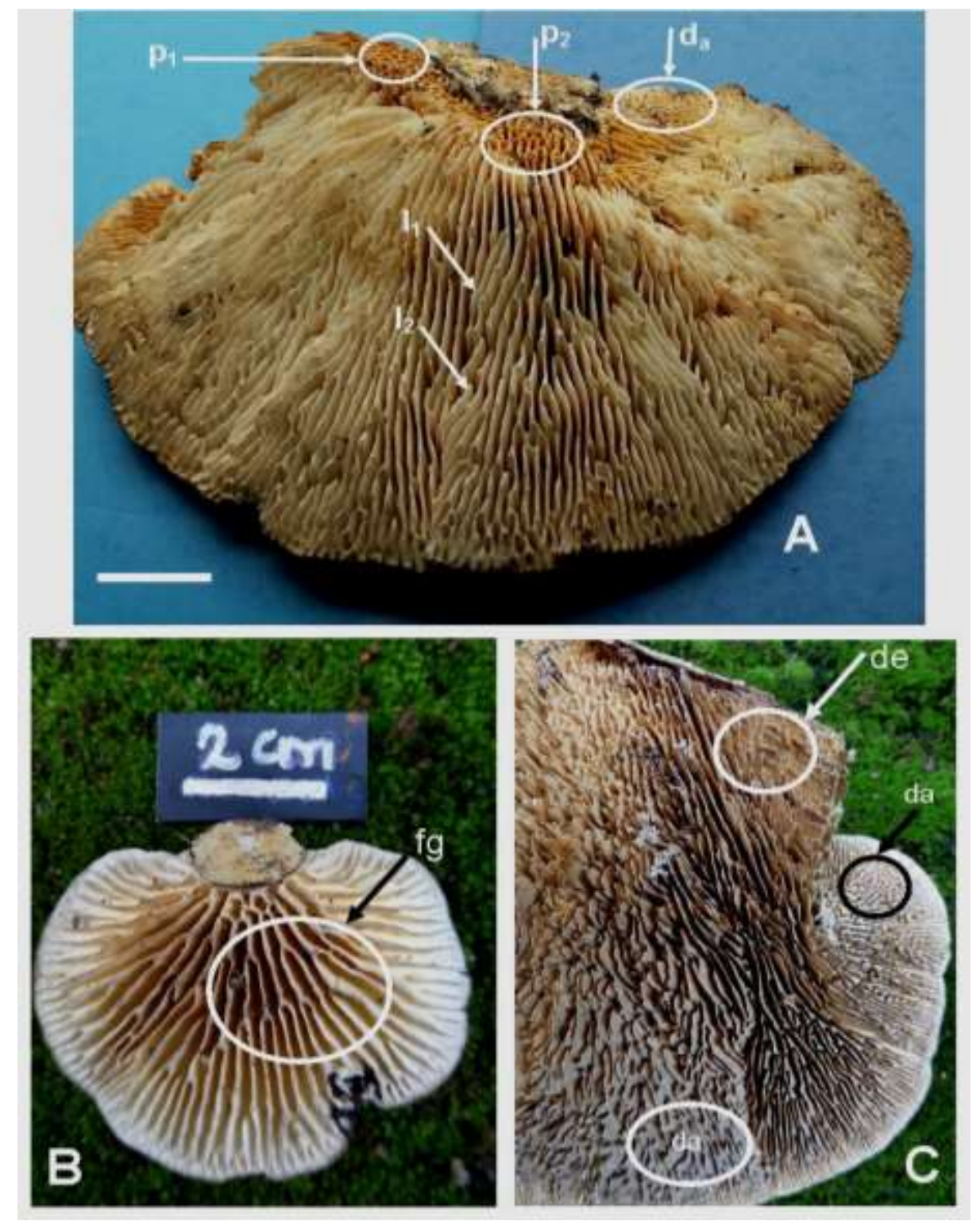

Fig. 2 - A Hymenophore of Artolenzites acuta comb. nov. : $1_{1} / l_{2}$ lamellate. $\mathrm{p}_{1} / \mathrm{p}_{2}$ poroid. da daedeloid. B Forking gills (fg) of the lamellate hymenophore of a young basidiocarp of Artolenzites acuta comb. nov. C Hymenophore morphology of a mature to old basidiocarp of Artolenzites acuta comb. nov. : da daedeloid. de subdentate to dentate. Scale bar $\mathrm{A}=3 \mathrm{~cm}$.

basidioma some striking structures with a succession of bifurcations and subbifurcations in form of forking gills (fg) (Fig. 2B-fg \& Fig. 2A-1 ) from the base to the borders of the hymenophore. Moreover and contrary to young specimens showing continuous lamellae with \pm entire edge (Fig. $2 \mathrm{~A}$ ) from base to margins, old (and dry) basidiocarps most often rather show \pm fragmented lamellae zonewise with subdentate to dentate (Fig. 2C-de) edges. When lamellate, lamellae measure 0.5-2.3 $\mathrm{cm}$ wide, are cream colour, beige-ochraceous (4A2-4A3) to pale-orange (5A3-5B3 to 6D4) on their upper half on fresh basidiocarps and rather cream or beige-ochraceus (4A2) to yellowish (4A54A6) on the lower half merging with the context. When daedaleoid (Fig.2A-da \& Fig. 2C-da), lamellae measure just about $0.5 \mathrm{~cm}$ wide and on poroid zones of the hymenophore, the pores are mostly angular (Fig. 2A/p1-p2), rarely circular, subhexagonal, square or rectangular with pore mouth measuring 1-6 mm diameter and $0.8-1.8 \mathrm{~cm}$ deep. Context relatively thin, measuring just about 2-5 mm thick at the base, beige to yellowish (4A5-4A6).

Hyphal system - trimitic, generative hyphae with clamps, hyaline 1.4-2.8 $\mu \mathrm{m}$ wide; skeletal hyphae (Fig. 4K) unbranched, pale yellowish, hyaline in $\mathrm{KOH}$, measuring 2-7.2 $\mu \mathrm{m}$ wide 

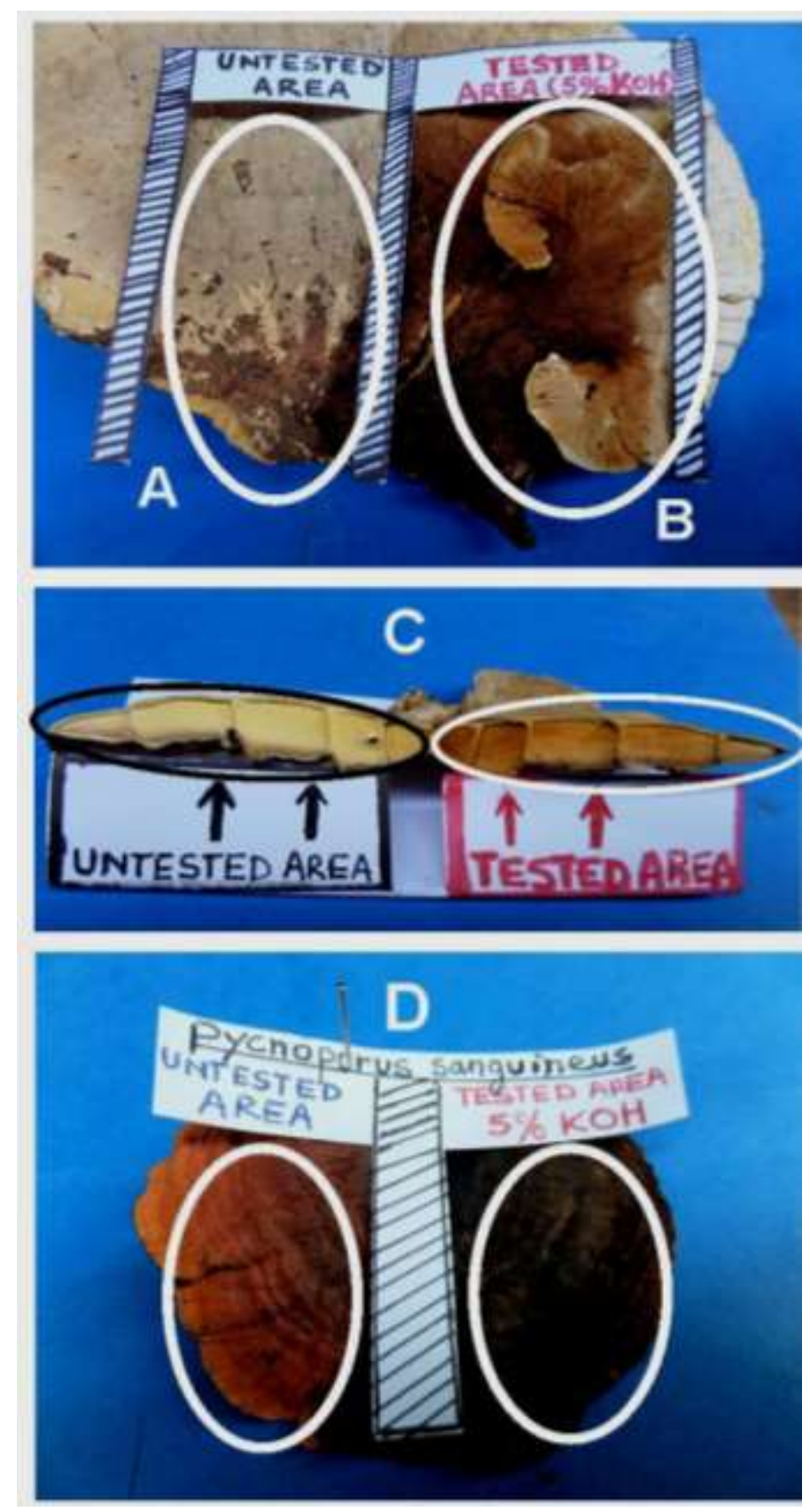

Fig. 3 - Colorimetric reaction of pileus (A/B) and lamellae-context ( C ) of Artolenzites acuta comb. nov. to $5 \% \mathrm{KOH}$, all becoming pale (sordid) yellow on the "TEST AREA". D Contrast reaction (blackening of the "TEST AREA") of 5\% KOH test on pileus of Pycnoporus sanguineus (Ref. Appendix Table 3).

with a lumen varying between $0.1(0.5)-6.5 \mu \mathrm{m}$; binding hyphae (Fig. 4L) richly branched, solid (Fig. 4J) or with a \pm narrow lumen (Fig. $4 \mathrm{G} / \mathrm{H}$ ), projecting rounded (Fig. $4 \mathrm{G}$ ) to subulate or swordlike (Fig. $4 \mathrm{H}$ ) structures \pm perpendicular to the hymenium (Fig. 4F) and measuring about 85-130 $\mu \mathrm{m}$ long and 2-8 $\mu \mathrm{m}$ diameter. Cystidia cystidia absent, but subulate to rounded binding hyphae in form of "pseudocystidia" (Fig. 4G/4H) projecting from hymenium (Fig. 4F). Basidia not seen. Basidiospores subcylindrical to cylindrical (Fig. 4I), 5.8-8.2 $\mu \mathrm{m} \times 2.2-3 \mu \mathrm{m}$, thin-walled, hyaline, inamyloïd. Pileipellis showing intermixed simple thin-walled hyphae (Fig. 4M) measuring 1.5-2 $\mu \mathrm{m}$ without incrustations and showing no traces of hyphal parietal crystals.

Habitat - on dead trunks or stumps of unidentified angiosperms in forestry zones opened to sunshine. 


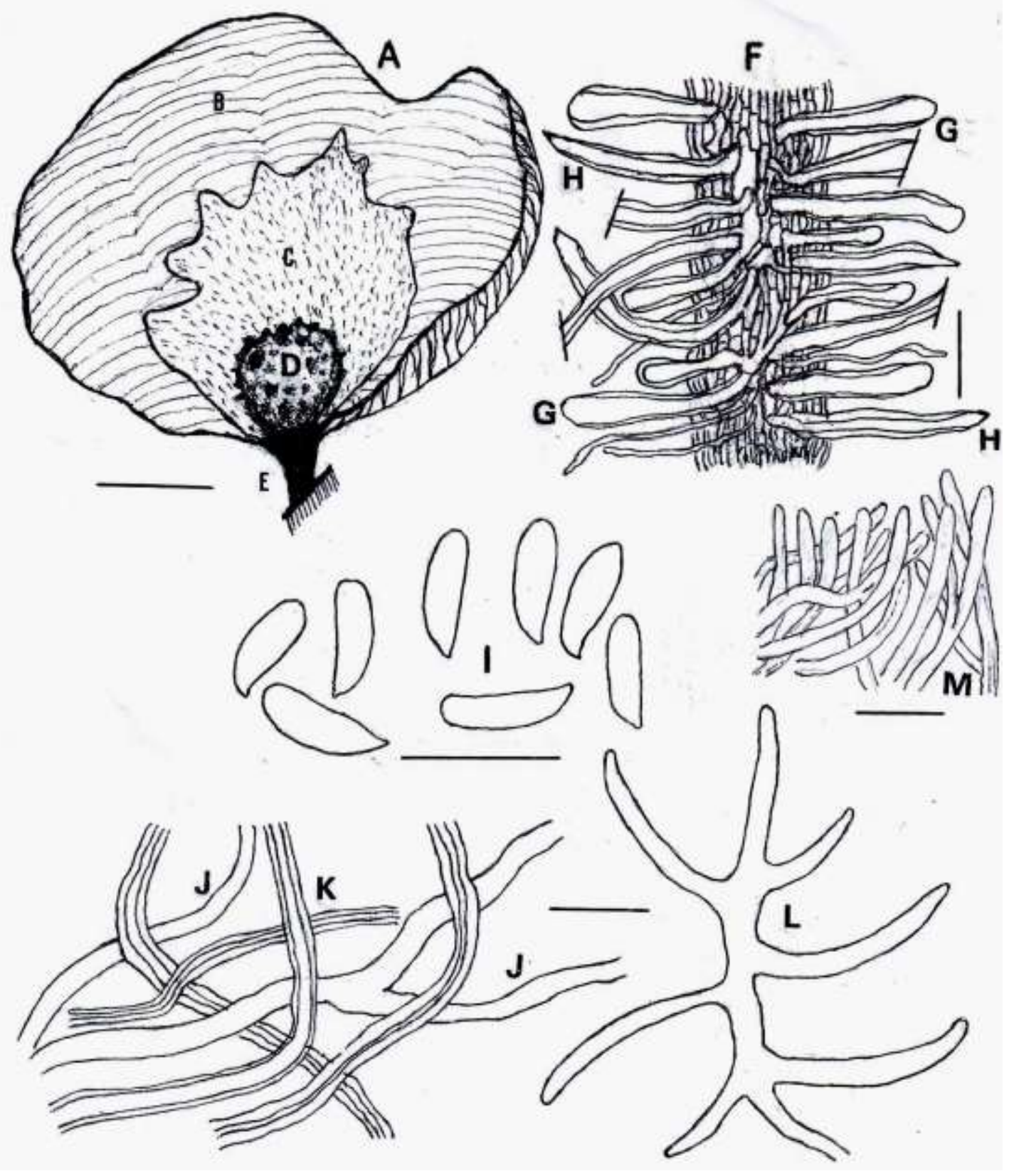

Fig. 4 - A Basidiocarp (HUY1-DM 456) of Artolenzites acuta comb. nov. B concentrically zonate part of the pileus. C Basal part of the pileus contrasting in colour. D Disk at the base of the pileus towards the attachment point to the substrate. E Attachment to the substrate contracted into a stemlike base. F Section through the hymenium showing various hymenial structures. G Rounded binding hyphae ("pseudocystidia") with lumen projecting from the hymenium. H Subulate to swordlike binding hyphae projecting from hymenium. I Basidiospores. J Solid binding hyphae from context. K Skeletal hyphae from context. L Branched binding hyphae from context. M Pileipellis showing intermixed hyphae without incrustations. Scale bar: $A / B / C / D / E=4 \mathrm{~cm}$, $\mathrm{F} / \mathrm{G} / \mathrm{H}=10 \mu \mathrm{m}, \mathrm{I}=10 \mu \mathrm{m}, \mathrm{J} / \mathrm{K} / \mathrm{L}=20 \mu \mathrm{m}, \mathrm{M}=10 \mu \mathrm{m}$.

Distribution - Artolenzites acuta was so far collected mainly in Asia, from Pakistan to China, Japan, Far East Russia, Thailand to tropical South East Asia and Australia. According to Ryvarden (pers. comm.) our specimen HUY1-DM 456 collected in 2006 was the first collected in Africa, since this species was not yet reported in this continent before this collection. 
Table 3 - Response (Yes, No, n/a ) of the samples tested or compared with regards to the 36 characteristics (Ref. case 1 to 36 in the table below)) of genera and species groups in the Trametes-group as described by Welti et al. (2012)

\begin{tabular}{|c|c|c|c|c|c|c|}
\hline $\begin{array}{l}\text { Morphologic } \\
\text { features } \rightarrow \\
\text { Genus } \downarrow\end{array}$ & Upper surface & $\begin{array}{l}\text { Hyphal Parietal } \\
\text { Crystals }\end{array}$ & $5 \% \mathrm{KOH}$ reactivity & $\begin{array}{l}\text { Attachment to the } \\
\text { substrate }\end{array}$ & Hymenophore & 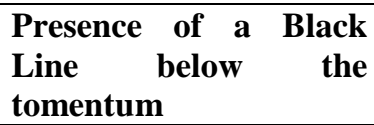 \\
\hline Trametes & $\begin{array}{l}\text { Pubescent to hirsute } \\
\text { (1) No }\end{array}$ & $\begin{array}{l}\text { None }- \text { except } T \text {. } \\
\text { versicolor: } \quad \text { blue } \\
\text { soluble in KOH 5\% } \\
\text { (2) n/a }\end{array}$ & $\begin{array}{l}\text { Context and abhymenial } \\
\text { surface sordid yellow - } \\
\text { except } T \text {. polyzona and } \\
\text { abhymenial surface of } \\
T \text {. versicolor which are } \\
\text { deep brown }(3) \mathrm{n} / \mathrm{a}\end{array}$ & $\begin{array}{l}\text { Never contracted into a } \\
\text { stem-like base } \\
\text { (4) No }\end{array}$ & $\begin{array}{l}\text { Regularly pored or radialy } \\
\text { elongated, deadaleoid to } \\
\text { lamellae. Dentate when } \\
\text { pored }(T \text {. versicolor }-T \text {. } \\
\text { maxima) }(5) \mathrm{n} / \mathrm{a}\end{array}$ & $\begin{array}{l}\text { Sometimes for } T \text {. } \\
\text { belutina. T. hirsula, } T \text {. } \\
\text { versicolor, Always into } \\
\text { the Always into the } \\
\text { meyenii subclade } \\
\text { (6) } \\
\text { n/a }\end{array}$ \\
\hline Pycnoporus & $\begin{array}{l}\text { Glabrous-dull } \\
\text { (7) Yes }\end{array}$ & $\begin{array}{l}\text { Orange to red soluble } \\
\text { in } \mathrm{KOH} 5 \% \\
\text { (8) No }\end{array}$ & $\begin{array}{l}\text { Black (Ref. Fig. 3D) } \\
\text { (9) No }\end{array}$ & $\begin{array}{l}\text { Contracted into a stem- } \\
\text { like base }- \text { sometimes } \\
\text { with a disc (10) Yes }\end{array}$ & $\begin{array}{l}\text { Regularly pored } \\
\text { (11) No }\end{array}$ & $\begin{array}{l}\text { Never } \\
(12) \text { Yes }\end{array}$ \\
\hline Leiotrametes & $\begin{array}{l}\text { Glabrous-dull } \\
\text { (13) Yes }\end{array}$ & $\begin{array}{l}\text { None } \\
(14) \text { Yes }\end{array}$ & $\begin{array}{l}\text { Context pale brown- } \\
\text { abhymenial surface deep } \\
\text { brown (15) No }\end{array}$ & $\begin{array}{l}\text { Contracted into a stem- } \\
\text { like base - sometimes } \\
\text { with a disc (except for } \\
\text { the sessile L. lactinea) } \\
\text { (16) Yes }\end{array}$ & $\begin{array}{l}\text { Regularly pored becoming } \\
\text { daedalean to lamellate } \\
\text { (17) No }\end{array}$ & $\begin{array}{l}\text { Never } \\
(18) \text { Yes }\end{array}$ \\
\hline Artolenzites & $\begin{array}{l}\text { Glabrous-dull } \\
(19) \\
\text { Yes } \\
\text { (Ref. Fig. 1A1/A2) }\end{array}$ & $\begin{array}{l}\text { None } \\
(20) \\
\text { Yes } \\
\text { (Ref. Fig. 4M) }\end{array}$ & $\begin{array}{l}\text { Sordid yellow } \\
(21) \\
\text { Yes } \\
\text { (Ref. Fig. 3A/B/C ) }\end{array}$ & $\begin{array}{l}\text { Contracted into a stem- } \\
\text { like base }- \text { sometimes } \\
\text { with a disc (22) } \\
\text { Yes (Ref. Figs. 1E/4E) }\end{array}$ & $\begin{array}{l}\text { Pored, deadalean to } \\
\text { lamellate often in a single } \\
\text { specimen-irregular (23) } \\
\text { Yes (Ref. Figs. 2A/B/C) }\end{array}$ & $\begin{array}{l}\text { Never } \\
(24) \\
\text { Yes }\end{array}$ \\
\hline $\begin{array}{l}\text { T. ljubarskyi- } \\
\text { T. cingulata }\end{array}$ & $\begin{array}{l}\text { Glabrous-dull to semi } \\
\text { glossy } \\
(25) \text { No }\end{array}$ & $\begin{array}{l}\text { Colorless, becoming } \\
\text { black with } \mathrm{KOH} 5 \% \\
\text { for T. cingulated } \\
(26) \mathrm{No}\end{array}$ & $\begin{array}{l}\text { Deep brown }(T . \\
\text { ljubarskyi) to strongly } \\
\text { black }(T . \text { cingulata })(27) \\
\text { n/a }\end{array}$ & $\begin{array}{l}\text { Never contracted into a } \\
\text { stem-like base (28) No }\end{array}$ & $\begin{array}{l}\text { Regularly pored } \\
\text { (29) No }\end{array}$ & $\begin{array}{l}\text { Never } \\
\text { (30) Yes }\end{array}$ \\
\hline L. warnieri & $\begin{array}{l}\text { Glabrous-dull } \\
\text { (31) Yes }\end{array}$ & $\begin{array}{l}\text { None } \\
(32) \text { Yes }\end{array}$ & $\begin{array}{l}\text { Context pale brown- } \\
\text { abhymenial surface deep } \\
\text { brown (33) No }\end{array}$ & $\begin{array}{l}\text { Never contracted into a } \\
\text { stem-like base } \\
\text { (34) No }\end{array}$ & $\begin{array}{l}\text { Regularly lamellate } \\
\text { (35) No }\end{array}$ & $\begin{array}{l}\text { Never } \\
\text { (36) Yes }\end{array}$ \\
\hline
\end{tabular}

"Appendix Table 3" above is based on "Table 3" from Welti et al. (2012)

Yes: the characteristic as described by authors (Welti et al. 2012) in Appendix Table 3 applies \pm conspicuously or was tested positively on the samples investigated

No: the characteristic as described by authors in Appendix Table 3 does not apply or was tested negatively on the samples investigated

n/a : (not applicable): the characteristic as described by authors in Appendix Table 3 does not apply to the genus Artolenzites. 
Type of rot - brown, since lamellae of young fresh basidiocarp tested negative in the alcoholic solution of guaïc showing just a late appearing and very faint and evanescent blueish colour.

$\mathrm{KOH}$ reactivity - shows various tints of pale (sordid) yellow (Fig. 3B-C) on pileus, context and hymenial surfaces.

\section{Remarks}

Artolenzites acuta is particularly characterized by its glabrous and \pm concentrically zonate pileus, the mixed structures of the hymenophore which is most often lamellate, but also poroid and daedeloid, all three structures sometimes found on the same hymenophore which could be also partly subdentate to dentate particularly on old lamellate basidiocarps. One of the main macroscopic peculiarities of this species is the dichotomous forking lamellae with bifurcations and subbifurcations from the base (attachment point to the substrate) of the hymenophore to the borders of the pileus which could be either uniformly coloured or most often for tropical specimens from Africa in particular, rather multicoloured showing various tints from base to borders as described above. The contraction of the attachment structure to the substrate into a stem-like base with the presence of a disc at the base as described by Ryvarden \& Johansen (1980), Nŭnez \& Ryvarden (2001) and later on completed by Welti et al. (2012) well match most of our specimens considering that all these features are rarely present on the same basidiocarp.

The KOH reactivity differential test set up by Welti et al. (2012) was successfully carried out (Fig. 3A/B/C) for the first time on Artolenzites acuta with a differential test as well carried out on Pycnoporus sanguineus (Fig. 3D). The results recorded on both tests well match those reported (Appendix Table 3) by the above mentioned authors. The negative test of the alcoholic solution of guaï carried out on hymenophore lamellae corroborates the results earlier obtained by Rathod (2012) on Lenzites acuta from India, thereby confirming the brown rot fungus status of Artolenzites acuta.

At macroscopical level, the closest species to Artolenzites acuta is Artolenzites elegans and they are so far the only two described species in the genus Artolenzites. However, Artolenzites elegans shows smaller pores and much smaller, but denser lamellae without or inconspicuous forking structures. Also the pileus of Artolenzites elegans which reacts similarly to the $\mathrm{KOH}$ test is rather uniformly white, whitish to grayish white or ochraceous when dry, showing no colour variations or a variegated pileus as generally described in Artolenzites acuta.

At microscopic level, it is worth mentioning that Artolenzites acuta is characterized by subcylindrical to cylindrical basidiospores, unbranched skeletal hyphae showing a lumen of various diameter and the subulate or swordlile to rounded binding hyphae projecting \pm perpendicularly from the hymenium. However at microscopic level, Artolenzites acuta mainly differs from the other genera of the Trametes-group (Appendix Table 3) by the absence of a resinous accumulation in the upper surface of skeletal hyphae (Fig. 4K) and the absence (Fig. 4M) of parietal crystals on hyphae from the pileipellis. Although slight differences in the measurements of either basidiospores, generative, skeletal or binding hyphae could be found respectively on the description of the first records of Lenzites acuta in Costa Rica and Panama (González-Ball et al. 2004) and those collected in the region of Western Maharasta in India (Rathod 2011), the features of their trimitic hyphal system is comparable to those described here in the first African record of Artolenzites acuta.

\section{Conclusion}

Appendix Table 3 shows that compared to the morphologic features of the 6 genera (or species) described by Welti et al. (2012), all samples investigated (HUY1-DM 456, DM 482, DM 575 , DM 865) responded positively or match \pm conspicuously only the whole set of 6 characteristics $\left(\mathrm{N}^{\circ} 19,20,21,22,23 \& 24\right)$ of the genus Artolenzites, leading to the conclusion that these samples well belong to the genus Artolenzites. 


\section{Acknowledgements}

The authors are very grateful to Emeritus Professor Leif Ryvarden of the University of Oslo in Norway for cross-checking our preliminary identification and helping us in determining the initial identity of the specimens described. We are also grateful to the Cameroon Ministry of higher education for the special support fund for research thanks to which part of the field and laboratory work was carried out.

\section{References}

Ambit RT. 2011 - Contribution to the taxonomic and ethnomycological study of Macromycetes growing in Mbengwi (North-West region) and surrounding areas in Cameroon. M.Sc thesis, Faculty of Science, University of Yaoundé 1, Cameroon, 87 p.

Charbonnel J. 1995 - Les réactifs mycologiques. Tome 1. Les réactifs macrochimiques. Edité par l'auteur. 344 p.

Erb B, Matheis W. 1983 - Pilzmikroskopie. Präparation und Untersuchung von Pilzen mit 135 Farbfotos. Kosmos, Stuttgart. 166 p.

González-Ball R, Ruiz-Boyer A, Carranza J. 2004 - Lenzites acuta Berk (Polyporaceae, Polyporales), un Nuevo registro para Costa Rica y Panamá. Brenesia 62, 75-75.

Kengni Ayissi MB, Mossebo DC, Machouart MC, Kansci G, Tsigaing TF, Dogang LR, Metsebing BP, Djifack NM. 2014 - A new method by correlation to forecast the optimal time of spore-prints production and collection on sporocarps of Ganoderma resinaceum Boud. (Basidiomycota) on natural substrate. Mycosphere 5(6), 758-767. Doi: 10.5943/Mycosphere/5/6/

Kirk PM, Cannon PF, Minter DW, Stalpers JA. 2008 - Dictionary of Fungi, $10^{\text {th }}$ edition. CABIEurope-UK. 771 p.

Kornerup A, Wansher JH. 1978 - Methuen handbook of colour. 3rd edn. Eyre Methuen, London. $252 \mathrm{p}$.

Mossebo DC, Njouonkou AL, Courtecuisse R, Amougou A. 2007 - Enzymatic activities and decay characteristics in some wood-rotting Basidiomycetes from Cameroon and determination of the time-dependant activity of syringaldazine in spot tests. Cryptogamie-Mycologie 28(2), $107-121$.

Mossebo DC. 2005 - Contribution à la connaissance de la flore mycologique tropicale : Inventaire, taxonomie et systématique des collections de Basidiomycètes (Macromycètes) du Cameroun et d'Afrique centrale. Mémoire d'Habilitation à Diriger des Recherches (HDR), Université de Lille 2, France. 127 p.

Mossebo DC, Ryvarden L. 2003 - The Genus Mycorrhaphium in Africa. Mycotaxon 88, 229 -232.

Mossebo DC, Ryvarden L. 1997 - Fomitopsis africana sp. nov. (Polyporaceae, Basidiomycotina). Sydowia 49(2), 147-149.

Nŭnez M, Ryvarden L, 2001 - East Asian Polypores. Vol. 2. Polyporaceae s. lato. Synopsis Fungorum 14, Fungiflora (edn.), Blindern, Oslo, Norway. 522 p.

Rathod MM. 2011 - Taxonomic studies on the Daedaloid and Hexagonoid Polypores from the forest of Western Maharasta. Recent Research in Science and Technology 3(5), 50-56.

Ryvarden L, Melo I. 2014 - Poroid fungi of Europe. Synopsis Fungorum 31. 455 p. Fungiflora, Oslo, Norway. 455 p.

Ryvarden L. 1992 - Genera of Polypores; nomenclature and taxonomy. Synopsis fungorum 5. Fungiflora (ed.), Oslo, Norway. 292 p.

Ryvarden L, Johansen I. 1980 - A Preliminary Polypore Flora of East Africa, Fungiflora (ed.), Oslo. $636 \mathrm{p}$.

Teixeira AR. 1986 - New name and new combinations in the Polyporaceae. In: Revista Brasileira Botânica 9(1), 43-44.

Welti S, Moreau PA, Favel A, Courtecuisse R, Haon M, Navarro D, Taussac S, Lesage-Meessen L. 2012 - Molecular phylogeny of Trametes and related genera and description of a new genus Leiotrametes. Fungal Diversity 55, 47-64. Doi: 10.1007/s13225-011-0149-2. 